Alina Zavadzka Archiwum i Muzeum Archidiecezji Białostockiej

\title{
Likwidacja Wileńskiego Seminarium Duchownego w 1945 roku
}

\section{LIQUIDATION OF VILNIUS SEMINARY AND DISPLACEMENT TO BIALYSTOK IN 1945}

The seminary in Białystok was formed as a result of a closure of a Seminary in Vilnius, which was founded by the bishop of Vilnius Jerzy Radziwiłł on 11th January 1582.

In 1925 the Vilnius Seminary was merged with the Theological Department of Stefan Batory University (USB). In December 1939 USB was liquidated, however the Theological Department acted in secret. After mass arrests of professors and clerical students, in March 1942 bishop Romuald Jałbrzykowski and Rev. Adam Sawicki were imprisoned. A seminary was liquidated and was not reopned until October 1944.

Unfortunately, authorities closed the Vilnius Seminary on 20th February 1945. Bishop R. Jałbrzykowski made a decision to move the Seminary to Białystok, where in spring, on the 8th of May 1945 it commenced its activity. A month later an order was given to remove the archbishop R. Jałbrzykowski from Vilnius. He left for Bialystok on 15th July 1945. From here he managed the part of the Vilnius archdiocese which stayed within the Poland's borders.

Key words: The seminary in Vilnius, Seminary in Białystok, liquidation, bishop Romuald Jałbrzykowski, Vilnius archdiocese.

Archidiecezjalne Wyższe Seminarium Duchowne w Białymstoku powstało w wyniku przemian politycznych w czasie drugiej wojny 
Historia Kościoła

światowej i jest spadkobiercą tradycji Seminarium Duchownego w Wilnie.

11 stycznia 1582 roku bp Jerzy Radziwiłł ${ }^{1}$ założył Seminarium Duchowne w Wilnie, którym początkowo opiekowali się jezuici. Zawiłe wydarzenia historyczne uniemożliwiały funkcjonowanie uczelni. Swej działalności nie mogło kontynuować w czasie inwazji rosyjskiej (zakończonej w 1661 roku), po Powstaniach Listopadowym i Styczniowym. Nauka przerwana została również w latach I wojny światowej i seminarium otwarto dopiero w roku 1920, gdy Wilno wraz z Wileńszczyzną zostało przyłączone do Polski.

Szczególną troską otaczali seminarium bp Jerzy Matulewicz ${ }^{2}$ i bp Romuald Jałbrzykowski³ , który w roku 1926 został Arcybiskupem

$1 \quad$ Jerzy Radziwiłł ur. się 31 maja 1556 roku koło Wilna. Święcenia kapłańskie i sakrę biskupią przyjął w 1583 roku. Biskup krakowski i wileński. Zmarł 21 stycznia 1600 r. w Rzymie.

2 Jerzy Bolesław Matulewicz (Jurgis Matulaitis-Matulevičius) ur. się 13 kwietnia 1871 roku w Lugine, k. Mariampola (na Litwie). Do 1893 roku był w Seminarium Duchownym w Kielcach i następne dwa lata w Seminarium Duchownym w Warszawie. Ukończył Akademię Duchowną w Petersburgu, w 1898 roku przyjął święcenia kapłańskie, a we Fryburgu uzyskał dyplom doktora teologii dogmatycznej. Kierował Stowarzyszeniem Mariańskim Świeckich Kapłanów w Warszawie. Odnowił i zreformował Zakon Marianów. W roku 1909 złożył śluby zakonne. Założył domy marianów w Chicago, Warszawie, Mariampolu. Założył dwa żeńskie zgromadzenia: w Kownie, w roku 1918, Zgromadzenie Sióstr Ubogich od Niepokalanego Poczęcia i w roku 1923 Zgromadzenie Służebnic Jezusa w Eucharystii (działające wśród ludności białoruskiej). W 1918 roku został mianowany przez Benedykta XV biskupem wileńskim, jednak w 1925 zrezygnował z funkcji zarządzania diecezją i opuścił Wilno. W tymże roku został mianowany wizy tatorem apostolskim na Litwę. Przygotował projekt nowej litewskiej administracji kościelnej, dostosował ją do granic państwowych. Przyczynił się do zawarcia konkordatu Litwy z Watykanem. Zmarł 27 stycznia 1927 roku w Kownie. 28 czerwca 1987 roku został beatyfikowany przez Jana Pawła II. P. Nitecki, Biskupi Kościoła w Polsce w latach 965-1999. Słownik biograficzny, wyd. 2, Warszawa 2000, kol. 287; Z. Proczek, Jerzy Matulewicz bł., [w]: S. Wielgus, J. Duchniewski (red.), Encyklopedia Katolicka, t. VII, Lublin 1997, s. 1228-1230.

Romuald Jałbrzykowski ur. się 7 lutego 1876 we wsi Łętowo-Dąb, w diecezji sejneńskiej. W roku 1893 wstąpił do Seminarium Duchownego w Sejnach i w roku 1898, jako diakon, został skierowany do Akademii Duchownej w Petersburgu. Święcenia kapłańskie przyjął 9 marca 1901 roku, a w roku następnym uzyskał stopień magistra teologii na tejże Akademii. W roku 1909 został wicerektorem Seminarium Duchownego i kanonikiem Kapituły Katedralnej w Sejnach. Podczas ofensywy niemieckiej w 1915, Seminarium Duchowne przeniesiono do Mohylewa, gdzie zostało rozwiązane. Ksiądz Jałbrzykowski udał się do Mińska, gdzie wszedł do zarządu Komitetu Obywatelskiego i pomagał uchodźcom. Wrócił do Polski. W roku 1918 został proboszczem w Radziłowie, w lipcu prekonizowany na biskupa tytularnego Kuzy i sufragana diecezji sejneńskiej. 
Metropolitą Wileńskim. Gmach seminaryjny mieścił się w klasztorze Karmelitów przy kościele św. Jerzego (ul. Mostowa). Od roku 1925 Wileńskie Seminarium Duchowne połączone było z Wydziałem Teologicznym Uniwersytetu Stefana Batorego. Klerycy uczęszczali na wykłady i zdobywali stopnie naukowe ${ }^{4}$.

Lata 1939-1944 spowodowały podziały polityczne i administracyjne Litwy, które miały wpływ na archidiecezję wileńską. Zmiany pojałtańskie zdecydowały o strukturalnym życiu Kościoła katolickiego. ArchiHistoria diecezję wileńską przecięły granice trzech państw: Polski, Litewskiej Republiki Sowieckiej i Białoruskiej Republiki Sowieckiej. Wilno wraz z Wileńszczyzną znalazły się po stronie Litewskiej SRS.

15 grudnia 1939 roku zlikwidowano Uniwersytet Stefana Batorego, jednak Wydział Teologiczny działał dalej potajemnie w gmachu tegoż seminarium $^{5}$. Rektorem Seminarium już od 30 lat był ks. Jan Uszyłło ${ }^{6}$. W 1939 roku pracowało tu ponad 20 księży wykładowców. Uczyło się tutaj 128 kleryków, którzy jednocześnie byli studentami Wydziału? W sierpniu i wrześniu 1940 roku władze Litewskiej Republiki Sowieckiej i państwowe instytucje sądowe zajęły gmach seminarium. Sprawa ta znalazła się w Komisariacie Spraw Wewnętrznych w Kownie, który po miesiącu odmówił seminarium prawa nauczania. Na mocy władz litewskich alumni musieli się kształcić w jednym z pozostawionych seminarium na całą Litwę - w Kownie. Jednak praca w roku akademickim 1940/41 odbywała się dalej w ciasnym lokalu seminarium

Zorganizował w Łomży Seminarium Duchowne i został jego pierwszym rektorem. Aktywnie angażował się w życie społeczne. 14 grudnia 1925 został pierwszym biskupem nowo utworzonej diecezji łomżyńskiej. 24 czerwca 1926 został mianowany Arcybiskupem Metropolitą Wileńskim. Na tym stanowisku pozostał do roku 1945. W latach 1942-1944 internowany w Mariampolu, rok później więziony na Łukiszkach w Wilnie. Od roku 1945 zarządzał Archidiecezją Wileńską z Białegostoku. Zmarł 19 czerwca 1955 w Białymstoku. P. Nitecki, Biskupi...,op. cit., kol. 164-165; S. Hołodok, Romuald Jałbrzykowski, [w]: S. Wielgus, J. Duchniewski (red.), Encyklopedia Katolicka, t. VII, Lublin 1997, kol. 737-738; A. Szot, Abp Romuald Jatbrzykowski metropolita wileński, Lublin 2002, s. 17-45. roku, „Studia Teologiczne” 5-6(1987-1988), s. 201-231.

Zob. T. Krahel, Wydziat Teologiczny USB i Wileńskie Seminarium Duchowne wlatach II wojny światowej, [w]: E. Feliksiak, A. Mironowicz (red.), Wilno i Kresy Pótnocno-Wschodnie. Materiaty II Międzynarodowej Konferencji w Biatymstoku 14-17 IX 1994 w czterech tomach, t. 1, Historia i ludzkie losy, Białystok 1996, s. 205-219. ks. Jan Uszyłło, ur. 1871, wyśw. 1894, zm. 1950.

Catalogus ecclesiarum et cleri archidioecesis Vilnensis pro Anno Domini 1939, Wilno 1939, s. 22-26. 
w Wilnie, gdzie liczba alumnów wynosiła 90 osób ${ }^{8}$ W następnym roku akademickim 1941/42 Seminarium prowadziło działalność pod okupacją niemiecką. Na początku władze zezwoliły na kontynuację nauki. Jednak na początku roku 1942 rozpoczęły się masowe aresztowania polskiego duchowieństwa. 3 marca tegoż roku gestapo i litewska policja (Sauguma) podczas wykładów aresztowały 15 profesorów razem z rektorem ks. Janem Uszyłło i 72 kleryków Wileńskiego Seminarium Duchownego. Osadzono ich w więzieniu na Łukiszkach, skąd kleryków zdolnych do pracy wywieziono do Niemiec ${ }^{9}$. Tego samego dnia uwięziono proboszczów i pracowników Kurii ${ }^{10}$. Tylko nieliczni uniknęli uwięzienia. 22 marca aresztowano i wywieziono abp. R. Jałbrzykowskiego i kanclerza Kurii ks. Adama Sawickiego ${ }^{11}$ do Wiłkowyszek. Metropolitę osadzono w klasztorze oo. Marianów w Mariampolu. Pozostał tu do sierpnia 1944 roku. Zrabowano sprzęt seminaryjny, zapasy żywnościowe, własność profesorów. Wileńskie Seminarium Duchowne zostało zlikwidowane i pracę rozpoczęło dopiero w październiku 1944 roku ${ }^{12}$.

Należy wspomnieć o seminarium, które abp Mečislovas Reinys ${ }^{13}$ otworzył w Wilnie podczas nieobecności metropolity abp R. Jałbrzykowskiego. Po zamknięciu przez Niemców Seminarium, w czerwcu 1942 roku abp M. Reinys wznowił działalność uczelni i na nowego rektora powołał ks. Ladasa Tulabę ${ }^{14} \mathrm{z}$ diecezji wiłkowyskiej. Mieściło się

8 AAB, W. Suszyński, Informacje o losach Wileńskiego Seminarium Duchownego $w$ czasie wojny od r. 1939 do dnia 5 sierpnia 1946 r., s. 2.

AAB, Garść informacyj z życia religijnego archidiecezji wileńskiej z lat 19401942, s. 1.

T. Krahel,Archidiecezja wileńska, [w]:Z.Zieliński(red.), Życie religijne w Polsce pod okupacja 1939-1945, Metropolia wileńska i lwowska, zakony, Katowice 1992, s. 33 . ks. Adam Sawicki, ur. 1887, wyśw. 1908, zm. 1968.

AAB, Sąd Arcybiskupi i Metropolitalny Wileński - Wilno, opieczętowany dn. 10 II 1948.

13 Mieczysław Reinys (Mečislovas Reinys) ur. 15 lutego 1884 we wsi Magadaskar w diecezji kowieńskiej. Studia seminaryjne rozpoczął w Wilnie, a ukończył w Petersburgu. Święcenia kapłańskie przyjął w roku 1907. Od roku 1914 pracował w Wilnie. Brał udział w antypolskiej działalności. W roku 1922 został wydalony do Kowna, gdzie wykładał na Uniwersytecie. Był również współzałożycielem Litewskiej Akademii Sztuki i Nauki. 5 kwietnia 1926 został konsekrowany na biskupa sufragana diecezji wiłkowyskiej. Po zajęciu przez Litwę Wileńszczyzny, dnia 18 lipca 1940 roku został mianowany arcybiskupem tytularnym Cypseli i sufraganem wileńskim. W roku 1947 aresztowany przez NKWD i zesłany na 25 lat katorgi pod zarzutem współpracy z podziemiem litewskim. Zmarł w roku 1953 we Władymirze k. Moskwy. P. Nitecki, Biskupi..., op. cit., kol. 378. 
ono w klasztorze benedyktyńskim przy kościele św. Michała w Wilnie. Było to seminarium litewskie. Rozpoczęło ono pracę 28 września 1942 roku, dokąd przebywali alumni z innych diecezji. Na dwóch latach studiów filozoficznych i czterech teologicznych uczyło się 44 kleryków narodowości litewskiej i białoruskiej. Mimo to, kilku kleryków narodowości polskiej ukończyło to seminarium ${ }^{15}$. Do kadry profesorskiej został włączony jeden Polak - ks. Jan Uszyłło. Jednak 19 marca 1943 władze niemieckie zażądały opuścić pomieszczenie seminarium, a uczelnia została zamknięte. Klerycy kontynuowali najpierw naukę samodzielnie, a po negocjacjach z władzami, w październiku 1943 roku zezwolono jednak na rozpoczęcie nowego roku akademickiego. W czerwcu 1944 sześciu kleryków otrzymało święcenia kapłańskie ${ }^{16}$. Latem 1944 roku działalność seminarium zostało przerwane.

Po wkroczeniu Armii Czerwonej do Wilna w lipcu 1944 roku, Wileńszczyzna znalazła się pod panowaniem sowieckim. Wrócił do Wilna abp Romuald Jałbrzykowski. Podjął się pracy nie tylko w ramach Litewskiej SRS, ale też i w Białoruskiej SRS ${ }^{17}$. W maju 1944 roku utworzono Radę ds. Kultów Religijnych, do kompetencji której należała kontrola działalności Kościoła katolickiego ${ }^{18}$. Plany rozwoju działań duszpasterskich zostały więc przerwane przez zarządzenia Rady ds. Kultów Religijnych i jej pełnomocnika. Podlegał on przewodniczącemu Rady Komisarzy Ludowych albo jego zastępcom.

Jak już wspomniałam, po zajęciu Wilna przez wojska sowieckie latem 1944 roku, do Wilna wrócili z obozów księża i m.in. profesorowie Seminarium Duchownego i Wydziału Teologicznego. Arcybiskup Romuald Jałbrzykowski nakazał wznowić Wileńskie Seminarium Duchowne, gdzie rok akademicki 1944/45 rozpoczął się w październiku ${ }^{19}$. Rektorem nadal był ks. J. Uszyłło, dziekanem Wydziału Teologicznego - potajemnie - ks. Michał Klepacz ${ }^{20}$. Przebywało w nim 68 kleryków

15 R. Laukaitytè, Archidiecezja wileńska w latach 1942-1944: pod wtadza Mečislovasa Reinysa, „Biuletyn Historii Pogranicza”, nr 9, Białystok 2008, s. 41.

LMAB, f. 318, t. 34325, k. 3 [Liber Ordinatorum, Vilniaus Arkivyskupijos dvasininkų sąrašai]. O działalności seminarium w latach 1942-1944 szerzej: L. Tulaba, Nuo Dusios iki Tiberio. Atsiminimai I, Roma 1993, s. 121-146; R. Laukaityté, Archidiecezja..., op. cit., s. 35-51.

A. Szot, Arcybiskup Romuald Jałbrzykowski na białostockiej ziemi (1945-1955), [w]: T. Kasabuła, J. J. Milewski (red.), Między Wilnem a Biatymstokiem. 50-lecie śmierci Arcybiskupa Romualda Jałbrzykowskiego, Białystok 2007, s. 75. LCVA, f. R-181, ap. 1, b. 236, k. 77 [Notatka P. Anilionisa z 19 IX 1979].

19 H. Gulbinowicz, Nadrogach życia, [w]: Życie-to wielka tajemnica. Wspomnienia ks. Antoniego Dilysa, oprac. L. Narkowicz, Wilno 2003, s. 7. ks. Michał Klepacz, biskup łódzki, ur. 1893, wyśw. 1916, zm. 1967. 
narodowości polskiej i litewskiej: na I roku - 21 kleryków, II - 17, III 4, IV - 15, V - 5, VI - 6 2 . Oprócz ks. Uszyłły i ks. Klepacza, pracowało jeszcze 17 profesorów, z nich dwaj Litwini: abp M. Reinys i ks. Vincentas Taškūnas ${ }^{22}$. Nauka odbywała się w przyspieszonym tempie, gdyż trwała jeszcze wojna, a nie było wiadomo, jak długo będzie istniała taka sytuacja dla seminarium.

Profesorów i kleryków wspierali duchowieństwo i wierni. Były skromne warunki, nie było prądu. Uczono trzech języków: polskiego, litewskiego i rosyjskiego. Metropolita dbał o to, aby każdy kleryk znał język litewski, gdyż znajomość jego była konieczna. Alumn mógł trafić do parafii, gdzie mieszkała duża liczba wiernych narodowości litewskiej i dla nich odprawiano nabożeństwa w tym języku².

Wraz ze zmianą granic na terenie Litwy parafie znalazły się w 9 dekanatach (w skład archidiecezji weszły parafie dekanatów, leżących na terenie Białorusi), w których pracowało 215 kapłanów diecezjalnych i zakonnych ${ }^{24}$. Należy zaznaczyć, iż pierwszą wstępną listę z danymi dotyczącymi stanu archidiecezji wileńskiej z drugiej połowy 1944 roku napisał rektor Wileńskiego Seminarium Duchownego ks. Jan Uszył$\mathfrak{ł o}^{25}$. Mimo niektórych braków, jest to bardzo cenny wykaz, ponieważ zawiera spis osobowy księży pracujących w Seminarium Duchownym w Wilnie, a także zakonów i zgromadzeń zakonnych męskich i żeńskich wraz z liczbą ich członków.

Prawie jednocześnie rozpoczęły się ingerencje władz w wewnętrzne sprawy Kościoła, a także w pracę duszpasterską. Na Wileńszczyźnie postanowiono rozwiązać przede wszystkim problem etniczny. Takim rozwiązaniem był „Układ pomiędzy Polskim Komitetem Wyzwolenia Narodowego a rządem Litewskiej Socjalistycznej Republiki Rad dotyczący ewakuacji obywateli polskich z terytorium Litewskiej SRS i ludności litewskiej z terytorium Polski" podpisany dnia 22 września 1944 roku $^{26}$. Miała być ona dobrowolna. Ewakuacja z lat 1944-1947

21 LCVA, f. R-181, ap. 1, b. 24, k. 49v-50 [Lista kleryków Rzym-Kat. Seminarium Duchownego w Wilnie]. Liczba kleryków wzrastała i już w styczniu 1945 roku było 73 kleryków. T. Krahel, Wydział Teologiczny USB..., op. cit., s. 216.

LCVA, f. R-181, ap. 1, b. 24, k. 49 [Lista profesorów Rzym-Kat. Seminarium Duchownego w Wilnie]; ks. Wincenty Taszkun (Vincentas Taškūnas), ur. 1880, wyśw. 1904, zm. 1967.

H. Gulbinowicz, Na drogach życia..., op. cit., s. 7-8.

Na podstawie: LCVA, R-181, ap. 1, b. 24, k. 79-94.

LMAB, f. 318, b. 22848, k. 1-4. do Polski 1944-1947, wybór, oprac. i red. dokumentów S. Ciesielski, Warszawa 
i 1956-1959 ludności polskiej z Wileńszczyzny doprowadziła do zmian demograficznych samego miasta Wilna, ale też i całego kształtu struktury narodowościowej w państwie ${ }^{27}$. Dotknęła ona inteligencję, duchowieństwo, żołnierzy Okręgu Wileńskiego $\mathrm{AK}^{28}$, mieszkańców miast, a także wsi, gdzie ludzie pracowali na roli i było ich najwięcej. Pod znakiem zapytania stał problem ewakuacji polskich sierot z wileńskich domów dziecka ${ }^{29}$.

Jednym z pierwszych posunięć władz było zamykanie Seminariów Kościoła Duchownych. 9 lutego 1945 roku Rada Komisarzy Ludowych przyjęła uchwałę, która zezwalała na działalność jedynie Kowieńskiego Seminarium Duchownego, co oznaczało zamknięcie trzech pozostałych seminariów w Wilnie, Telszach i Wiłkowyszkach.

W grudniu 1944 roku pełnomocnikiem Rady ds. Kultów Religijnych został Alfonsas Gailevičius ${ }^{30}$. Rozpracowano więc plan likwidacji Wileńskiego Seminarium Duchownego. Arcybiskupa Jałbrzykowskiego scharakteryzowano jako „zajadłego polskiego nacjonalistę”, a Seminarium zarzucono, że zaczęło swoją pracę nielegalnie, gdyż

1999, s. 55. O organizacji ewakuacji ludności polskiej z terenów Związku Sowieckiego piszą: K. Kersten, Repatriacja ludności polskiej po II wojnie światowej (studium historyczne), Wrocław 1987; J. Czerniakiewicz, Repatriacja ludności polskiej z ZSRR 1944-1948, Warszawa 1987; J. Siedlecki, Losy Polaków w ZSRR w latach 1939-1986, Londyn 1987; Zob. A. Paczoska, Powojenna ewakuacja ludności - sposób na rozwiązanie problemów etnicznych Wileńszczyzny, [w:] Opór wobec systemów totalitarnych na Wileńszczyźnie w okresie II wojny światowej, Gdańsk 2003, s. 81-93.

Ewakuacja miała miejsce także z Litwy etnicznej (w dwudziestoleciu międzywojennym nazywana Litwą Kowieńską). Punkty rejestracyjne znajdowały się w Kownie, Kiejdanach, Poniewieżu i w Wiłkomierzu. Litwę etniczną opuściło 1,8 tys. osób. K. Buchowski, Uwagi o tak zwanych repatriacjach ludności polskiej $z$ terenów Litwy etnicznej w latach 1945-1947, [w:] M. Kietliński, W. Śleszyński (red.), Repatriacje i migracje ludności pogranicza XX wieku. Stan badań oraz źódta do dziejów pogranicza polsko-litewsko-białoruskiego, Białystok 2004, s. 109.Zob. idem, Szkice polsko-litewskie czyli o niełatwym sasiedztwie w pierwszej połowie XX wieku, Torun 2006, s. 199-211.

Kierownictwo NKWD-NKGB Litewskiej SRS ścigało członków organizacji antysowieckich i uznało, że podziemna polska organizacja wykorzystywała procesy przesiedleńcze do określonych celów. Szerzej: V. Stravinskienė, Polska ludność Litwy Wschodniej i Potudniowo-Wschodniej w polu widzenia sowieckich stużb bezpieczeństwa w latach 1944-1953, „Biuletyn Historii Pogranicza”, nr 11, Białystok 2011, s. 57-72.

A. Srebrakowski, Polacy z Litwy, „Karta” 7(1992), s. 48-49.

Alfonsas Gailevičius (1910-1998) - piastował urząd pełnomocnika Rady ds. Kultów Religijnych przy Radzie Ministrów ZSRS na Litewską SRS w latach 1944-1947. Następnie do roku 1953 był zastępcą szefa Organów Bezpieczeństwa LSRS. 
nie poinformowano o tym władz ${ }^{31}$. W styczniu 1945 roku przeprowadzono rewizję w Kurii, kościele Świętego Ducha i czterech klasztorach $^{32}$. Aresztowano metropolitę Jałbrzykowskiego wraz z kanclerzem ks. A. Sawickim i kilkoma księżmi, byli to: Aleksander Lachowicz ${ }^{33}$, Lucjan Pereświet-Sołtan ${ }^{34}$, Giedymin Pilecki ${ }^{35}$, Antoni Cichoński ${ }^{36}$. Metropolita i ks. Sawicki znaleźli się w więzieniu NKGB na Łukiszkach. Sprawa abp. R. Jałbrzykowskiego przybrała zły obrót. Materiały Kościoła Organów Bezpieczeństwa i tajnej policji litewskiej „Saugumy” z okresu 1939-1940 negatywnie przedstawiały wileńskiego metropolitę w osobie działacza antylitewskiego. Arcybiskup Jałbrzykowski został oskarżony na podstawie art. 58-4 Kodeksu Karnego RSFSR (ros. Российской Социалистической Федеративной Советской Республики - Rosyjskiej Socjalistycznej Federacyjnej Sowieckiej Republiki) ${ }^{37}$. Zarzucono mu działalność i kontakty z polskim podziemiem w czasie okupacji niemieckiej oraz założenie antysowieckiej podziemnej organizacji Związku Walki Zbrojnej („,nacjonalistycznego podziemia”) i wrogość wobec państwa sowieckiego ${ }^{38}$. Zarzucono mu również, że nie popierał wyjazdu

$31 \quad$ I. Mikłaszewicz, Polityka sowiecka wobec Kościoła Katolickiego na Litwie 1944-1965, Warszawa 2001, s. 173. LCVA, R-754, ap. 13, b. 40, k. 110 [Dokładna notatka A. Guzevičiusa do M. Gedvilasa 31 III 1945]. ks. Aleksander Lachowicz, ur. 1895, wyśw. 1929, zm. 1978. ks. Lucjan Pereświet-Sołtan, ur. 1906, wyśw. 1933, zm. 1951. ks. Giedymin Pilecki, ur. 1903, wyśw. 1929, zm. 1967. ks. Antoni Cichoński, ur. 1892, wyśw. 1915, zm. 1961.

$\mathrm{Na}$ podstawie art. 58. skazywano wszystkich księży katolickich. Artykuł ten składał się z 14 punktów mówiących o przestępstwach politycznych i kontrrewolucyjnych. Punkt 4. tego artykułu mówił: „Okazywanie pomocy w jakiejkolwiek formie tej części burżuazji międzynarodowej, która, nie uznając równości prawnej systemu komunistycznego, wchodzącego na miejsce systemu kapitalistycznego, dąży do obalenia tego systemu, oraz pomaganie osobom znajdującym się pod wpływem lub będącym członkami organizowanych przez tę burżuazję grup i organizacji społecznych w realizowaniu wrogiej działalności wobec ZSRS, pociąga za sobą - pozbawienie wolności na okres nie mniejszy niż trzy lata z konfiskatą całego mienia, przy szczególnie obciążających okolicznościach podwyższenia środków prewencji społecznej - do najwyższego wymiaru kary lub uznania za wroga ludu pracującego włącznie z pozbawieniem obywatelstwa republiki związkowej, a tym samym obywatelstwa ZSRS, wypędzenie z terytorium ZSRS na zawsze i konfiskatę mienia". Fragment z 1 paragrafu 58 Kodeksu Karnego RSFSR.R.Dzwonkowski,Leksykon duchowieństwa polskiego represjonowanego $w$ ZSRS 1939-1988, Lublin 2003, s. 736. 
księży do Polski i nie godził się na wydanie odezwy do mieszkańców Wileńszczyzny w tej sprawie.

Arcybiskupa Jałbrzykowskiego przetrzymywano w bardzo złych warunkach. Zachorował na nerki i zapalenie płuc. Został zwolniony ze względu na stan zdrowia 20 lutego $1945 \mathrm{roku}^{39}$. Natomiast przesłuchania jego trwały do 25 maja tego roku ${ }^{40}$.

20 lutego 1945 roku NKWD otoczyło seminarium. Władze zamknęły uczelnię i cały sprzęt został skonfiskowany, a klerykom kazano opuścić Wilno. Ksiądz rektor J. Uszyłło wystosował pismo do Rady Komisarzy Ludowych SRS z prośbą o umożliwienie zakończenia roku akademickiego i zaznaczył, że o działalności Seminarium był poinformowany pełnomocnik Rady ds. Kultów Religijnych ${ }^{41}$. Arcybiskup R. Jałbrzykowski podjął decyzję o przeniesieniu Seminarium Duchownego z Wilna do Białegostoku. 4 marca 1945 roku Arcybiskup udzielił jeszcze święceń kapłańskich w katedrze wileńskiej ${ }^{42}$. Na podstawie umowy z 22 września 1944 roku ludność narodowości polskiej wyjeżdżała do Polski. Wyjeżdżali również profesorowie i klerycy. Klerycy narodowości litewskiej udali się do Kowna. Seminarium Wileńskie zostało przeniesione do Białegostoku i wiosną 8 maja tegoż roku rozpoczęło swoją działalnośćc ${ }^{43}$.

W dniu 4 czerwca 1945 roku Kolegium Specjalne NKWD ZSRS wydało rozkaz usunięcia metropolity z Wilna ${ }^{44}$. 15 lipca 1945 roku opuścił Wilno kierując się do Białegostoku ${ }^{45}$. Stąd zarządzał tą częścią Archidiecezji Wileńskiej, która została w granicach Polski. Kolejnymi transportami wyjeżdżali pozostali księża profesorowie i klerycy Wileńskiego Seminarium Duchownego. Ci, którzy przebywali czasowo $\mathrm{w}$ innych seminariach duchownych, mieli pozostać tam do złożenia

A. Szot, Abp Romuald Jałbrzykowski..., op. cit., s. 280.

LYA, f. K-1, ap. 58, b. P-14464 [Sprawa R. Jałbrzykowskiego. Akta śledcze].

LCVA, R-181, ap. 1, b. 6, k. 27 [Prośba do A. Gedvilasa od Rektora Wileńskiego Seminarium Duchownego 1 III 1945].

LMAB, f. 318, b. 34235, k. 4 [Liber Ordinatorum].

Zob. Archidiecezjalne Wyższe Seminarium Duchowne w Biatymstoku, oprac. E. Ozorowski, Białystok 1981; T. Krahel, Dzieje Archidiecezjalnego Wyższego Seminarium Duchownego w Biatymstoku, [w:]S. Hołodok(red.), Archidiecezjalne Wyższe Seminarium Duchowne w Biatymstoku 1945-1995. Księga Jubileuszowa, Białystok 1995, s. 9-45.

4 Wyrok Kolegium Specjalnego NKWD ZSRS z 4 VI 1945 w sprawie bpa Romualda Jałbrzykowskiego. I. Mikłaszewicz, Polityka..., op. cit., s. 239.

5 A. Szot, Abp Romuald Jałbrzykowski..., op. cit., s. 280-281. 
egzaminów i zakończenia roku akademickiego. Po zakończeniu roku mogli przybyć do Białegostoku ${ }^{46}$.

Ponad 80\% mieszkańców Litwy było katolikami. Zmiany polityczne po II wojnie światowej, pociągnęły za sobą ogromne cierpienia duchowieństwa i wiernych. Okres reżimu totalitarnego charakteryzował się planową ateizacją społeczeństwa, zaznaczony wieloma prześladowaniami, represjami w stosunku do Kościoła katolickiego. W Archidiecezji Wileńskiej ograniczano przede wszystkim działalność polskich duchownych, stosowano wobec nich represje i wymuszano ewakuację. W okresie powojennym Archidiecezją Wileńską zarządzali administratorzy apostolscy i wikariusze kapitulni. Po wydaleniu abp. Romualda Jałbrzykowskiego z Wilna, częścią Archidiecezji Wileńskiej po stronie państwa litewskiego administrował abp M. Reinys. Klerycy narodowości litewskiej naukę kontynuowali w Seminarium Kowieńskim ${ }^{47}$, a kandydatów do kapłaństwa narodowości polskiej z Archidiecezji Wileńskiej było w nim niewielu. Działalność Wileńskiego Seminarium Duchownego wznowił dopiero dekret z dnia 16 lutego 1993 roku wydany przez Metropolitę Wileńskiego abp. Audrysa Juozasa Bačkisa ${ }^{48}$.

Słowa klucze: Seminarium Duchowne w Wilnie, Seminarium Duchowne w Białymstoku, likwidacja, abp Romuald Jałbrzykowski, Archidiecezja Wileńska.

\section{Bibliografia:}

1. Archidiecezjalne Wyższe Seminarium Duchowne w Biatymstoku, oprac. E. Ozorowski, Białystok 1981.

2. Buchowski K., Szkice polsko-litewskie czyli o niełatwym sasiedztwie $w$ pierwszej połowie XX wieku, Torun 2006.

3. Buchowski K., Uwagi o tak zwanych repatriacjach ludności polskiej z terenów Litwy etnicznej w latach 1944-1947, [w:] M. Kietliński, W. Śleszyński

$46 \quad$ AAB, Protokół Sesji XX. Profesorów Wileńskiego Rzymsk.-Katolickiego Duchownego Seminarjum w Białymstoku z dnia 31 kwietnia 1945.

47 W roku 1970 zaczęło działać podziemne Seminarium, którego inicjatorem był ks. Juozas Zdebskis. Pochodził z parafii Krosno k. Mariampola. W Seminarium tym studiowało najpierw 4 kandydatów. W sierpniu 1971 roku ks. Juozas został aresztowany. Prowadzenie podziemnego Seminarium przejęły dwa zakony męskie: marianie i jezuici. Oprócz Litwinów byli tutaj klerycy z Białorusi, Ukrainy i Estonii. Pierwszym wyświęconym został Polak z Ukrainy, w roku 1980, Jan Paweł Lenga, późniejszy biskup Karagandy. Święcenia przyjęło ponad 30 osób. V. Spengla, Litewski Popietuszko?, „Lithuania” 4(33) 1999, s. 42-54; Zob. J. Boruta, V. Milius i in., Pogrindžio kunigu seminarija, Vilnius 2002. 
(red.), Repatriacje i migracje ludności pogranicza $w$ XX wieku. Stan badań oraz źródła do dziejów pogranicza polsko-litewsko-białoruskiego, Białystok 2004.

4. Catalogus ecclesiarum et cleri archidioecesis Vilnensis pro Anno Domini 1939, Wilno 1939.

5. Dekret Metropolity Wileńskiego abp. Audrysa Juozasa Bačkisa dn. 16 II 1993.

6. Dzwonkowski R., Leksykon duchowieństwa polskiego represjonowanego $w$ ZSRS 1939-1988, Lublin 2003.

7. Hołodok S., Romuald Jałbrzykowski, [w:] S. Wielgus, J. Duchniewski (red.), Encyklopedia Katolicka, t. VII, Lublin 1997.

8. Gulbinowicz H., Na drogach życia, [w:] Życie - to wielka tajemnica. Wspomnienia ks. Antoniego Dilysa, opr. L. Narkowicz, Wilno 2003.

9. Krahel T., Archidiecezja wileńska, [w:] Z. Zieliński (red.), Życie religijne $w$ Polsce pod okupacja 1939-1945, Metropolia wileńska i lwowska, zakony, Katowice 1992.

10. Krahel T., Dzieje Archidiecezjalnego Wyższego Seminarium Duchownego $w$ Białymstoku, [w:] S. Hołodok (red.), Archidiecezjalne Wyższe Seminarium Duchowne w Białymstoku 1945-1995. Księga Jubileuszowa, Białystok 1995.

11. Krahel T., Wydziat Teologiczny USB $i$ Wileńskie Seminarium Duchowne w latach II wojny światowej, [w:] E. Feliksiak, A. Mironowicz (red.), Wilno i Kresy Pótnocno-Wschodnie. Materiaty II Międzynarodowej Konferencji $w$ Biatymstoku 14-17 IX 1994 w czterech tomach, t. 1, Historia i ludzkie losy, Białystok 1996.

12. Laukaitytė R., Archidiecezja wileńska w latach 1942-1944: pod wtadza Mečislovasa Reinysa, „Biuletyn Historii Pogranicza”, nr 9, Białystok 2008.

13. Mikłaszewicz I., Polityka sowiecka wobec Kościoła Katolickiego na Litwie 1944-1965, Warszawa 2001.

14. Nitecki P., Biskupi Kościoła w Polsce $w$ latach 965-1999. Stownik biograficzny, wyd. 2, Warszawa 2000.

15. Spengla V., Litewski Popiełuszko?, „Lithuania” 4(33) 1999.

16. Boruta J., V. Milius i in., Pogrindžio kunigu seminarija, Vilnius 2002.

17. Srebrakowski A., Polacy z Litwy, „Karta” 7(1992).

18. Stravinskienė V., Polska ludność Litwy Wschodniej i Potudniowo-Wschodniej w polu widzenia sowieckich stużb bezpieczeństwa w latach 1944-1953, „Biuletyn Historii Pogranicza”, nr 11, Białystok 2011.

19. Szot A., Abp Romuald Jałbrzykowski metropolita wileński, Lublin 2002.

20. Szot A., Arcybiskup Romuald Jałbrzykowski na biatostockiej ziemi (19451955), [w:] T. Kasabuła, J. J. Milewski (red.), Między Wilnem a Biatymstokiem. 50-lecie śmierci Arcybiskupa Romualda Jatbrzykowskiego, Białystok 2007.

21. Piechnik L., Seminaria duchowne w (archi)diecezji wileńskiej do 1939 roku, „Studia Teologiczne” 5-6(1987-1988).

22. Proczek Z., Jerzy Matulewicz bt., [w:] S. Wielgus, J. Duchniewski (red.), Encyklopedia Katolicka, t. VII, Lublin 1997.

23. Tulaba L., Nuo Dusios iki Tiberio. Atsiminimai I, Roma 1993. 


\section{Źródła archiwalne}

1. Archiwum Archidiecezjalne w Białymstoku (AAB). Kolekcja dokumentów, bez sygn.

2. Litewskie Centralne Archiwum Państwowe (Lietuvos Centrinis Valstybès Archyvas - LCVA). Zespół: Pełnomocnik Rady do Spraw Kultów Religijnych przy Radzie Ministrów ZSRS na Litewską SRS, R-181, ap. 1. Zespół: Uchwały i materiały Rady Ministrów Litewskiej SRS, R-754, ap. 13.

3. Litewskie Archiwum Specjalne (Lietuvos Ypatingas Archyvas - LYA) . Zespół: Dokumenty i materiały NKWD-MGB-KGB Litewskiej SRS, K-1, ap. 58.

4. Biblioteka Litewskiej Akademii Nauk (Lietuvos Mokslo Akademijos Biblioteka - LMAB). Zespół: Kolekcja dokumentów Archidiecezji Wileńskiej, 318. 